\title{
Preface to Research on Applied Ethics (Cybersecurity)
}

\section{Matthew Warren}

Deakin University

matthew.warren@deakin.edu.au

\section{Oliver Burmeister}

\section{Charles Sturt University}

This is the second special section on applied ethics for AJIS. As was the case for the first special section on ethics, of the various submissions, only three have been accepted for publication. This is not an indication that little work is being done in relation to cybersecurity ethics, but rather a reflection of the difficulty of getting published in a high quality journal. A great deal of research is being done in the area of ethics as regards cybersecurity, particularly in Europe as a result of the recent toughening of its privacy legislation and the implications that has for all manner of ethics and technology, from blockchain, to wearable robots and through to cybersecurity. An overview of those three articles follows, after which the guest editor backgrounds are described.

The paper by Miller on 'Machine Learning, Ethics and Law' explores ethical machine learning issues concerning data firm Cambridge Analytica's illegitimate use of the data of millions of Facebook users. Its focus is on the three areas of profiling and predictive policing, legal adjudication, and machines' compliance with legally enshrined moral principles. The paper by Luck on 'Entrapment behind the firewall: the ethics of internal cyber-stings' addresses in part the focus of so much of the security literature, which reveals that the majority of breaches happen by insiders. It explores the ethical issues, such as trust, of conducting internal stings involving an organisation's own employees. The paper by Thomas et al. on 'The importance of ethical conduct by penetration testers in the age of breach disclosure laws' looks at ethical hacking in the light of breach disclosure laws, which are designed to protect privacy, such as the Notifiable Data Breaches scheme in Australia and the General Data Protection Regulation (GDPR) in the European Union. In relation to the ethical hacking paper, which was coauthored by one of the guest editors, it should be noted that he was not involved in any of the reviewing and editorial decision making for that paper. Instead those tasks were carried out by the Editor-in-Chief of AJIS. The AJIS editorial system was set-up such that Prof Burmeister could not see that submission, nor any processing of it.

Two guest editors were appointed, Professor Matthew Warren (Deakin University) and Professor Oliver Burmeister (Charles Sturt University). Professors Warren and Burmeister have collaborated in various ways over the past 20 years. They were both executive members of the Australasian Institute on Computer Ethics (AiCE) and have both been members of the Australian Computer Society's (ACS) Ethics Committee; Prof Burmeister still is. They are also both involved in the Cybersecurity Collaborative Research Centre (CRC), which has six research and 25 industry partners, as well as significant funding from the government to the amount of $\$ 139$ million over seven years. Professor Matthew Warren has published eight times in AJIS over the past 17 years (Senarathna, et al, 2018, Senarathna, et al, 2016, Pye and Warren 2006, Pierce, et al 2006, Leitch and Warren 2003, Warren and Hutchinson 2003, Hutchinson and Warren 2002a, Hutchinson and Warren 2002b, Hutchinson and Warren 2001). Professor Warren has served as a Chair of Information Systems, but for the past few years has been a Professor of Cyber Security at Deakin University. Professor Burmeister has also published 
multiple times in AJIS (Bowern, Burmeister, Gotterbarn, \& Weckert, 2006; Burmeister, 2015; Burmeister, Islam, Dayhew, \& Crichton, 2015; Burmeister et al., 2019; Islam, Miah, Kamal, \& Burmeister, 2019; Poulsen \& Burmeister, 2019; Simpson, Nevile, \& Burmeister, 2003). Most of his ICT ethics work been in the areas of value sensitive design (Burmeister, 2010, 2012, 2016; Burmeister \& Kreps, 2018; Burmeister, Weckert, \& Williamson, 2011; Teipel et al., 2016) and professional ethics (Burmeister, 2013, 2017).

\section{References}

Bowern, M., Burmeister, O. K., Gotterbarn, D., \& Weckert, J. (2006). ICT Integrity: Bringing the ACS Code of Ethics up to date. Australasian Journal of Information Systems, 13(2), 168-181. doi:http://dx.doi.org/10.3127/ajis.v13i2.50

Burmeister, O. K. (2010). Websites for seniors: Cognitive accessibility. International Journal of Emerging Technologies and Society, 8(2), 99-113.

Burmeister, O. K. (2012). What seniors value about online community. Journal of Community Informatics, 8(1).

Burmeister, O. K. (2013). Achieving the goal of a global computing code of ethics through an international-localisation hybrid. Ethical Space: The International Journal of Communication Ethics, 10(4), 25-32.

Burmeister, O. K. (2015). Improving professional IT doctorate completion rates. Australasian Journal of Information Systems, 19, 55-70. doi:10.3127/ajis.v19i0.1073

Burmeister, O. K. (2016). The development of assistive dementia technology that accounts for the values of those affected by its use. Ethics and Information Technology, 18(3), 185-198. doi:10.1007/s10676-016-9404-2

Burmeister, O. K. (2017). Professional Ethics in the Information Age. Journal of Information, Communication \& Ethics in Society, 15(4), 348-356.

Burmeister, O. K., Islam, M. Z., Dayhew, M., \& Crichton, M. (2015). Enhancing client welfare through better communication of private mental health data between rural service providers. Australasian Journal of Information Systems, 19, 1-14. doi:10.3127/ajis.v19i0.1206

Burmeister, O. K., \& Kreps, D. (2018). Power influences upon technology design for age-related cognitive decline using the VSD framework. Ethics and Information Technology, 20(3).

Burmeister, O. K., Ritchie, D., Devitt, A., Chia, E., Dresser, G., \& Roberts, R. (2019). The impact of telehealth technology on user perception of wellbeing and social functioning, and the implications for service providers. Australasian Journal of Information Systems, 23. doi:10.3127/ajis.v23i0.1501

Burmeister, O. K., Weckert, J., \& Williamson, K. (2011). Seniors extend understanding of what constitutes universal values. Journal of Information, Communication \& Ethics in Society, 9(4), 238-252. doi:10.1108/14779961111191048

Leitch, S. and Warren, M.J. (2003). Designing Systems for E-Commerce, Australian Journal of Information Systems, Vol 10, No 2. http://dx.doi.org/10.3127/ajis.v10i2.161

Hutchinson, W. and Warren, M.J. (2002). Information Warfare: using the viable system model as a framework to attack organisations, Australian Journal of Information Systems, Vol 9, No 2. http://dx.doi.org/10.3127/ajis.v9i2.193 
Islam, M. R., Miah, S. J., Kamal, A. R. M., \& Burmeister, O. K. (2019). A Design Construct Developing Approaches to Measure Mental Health Conditions. Australasian Journal of Information Systems, Vol 23. http://dx.doi.org/10.3127/ajis.v23i0.1829

Poulsen, A., \& Burmeister, O. K. (2019). Overcoming carer shortages with care robots: Dynamic value trade-offs in run-time. Australasian Journal of Information Systems, 23. doi:10.3127/ajis.v23i0.1688.

Pierce, J., Jones, A. and Warren, M.J. (2006). Penetration Testing Professional Ethics: A Conceptual Model and Taxonomy, Australasian Journal of Information Systems, Vol 13, No 2. http://dx.doi.org/10.3127/ajis.v13i2.52

Pye, G. and Warren, M.J. (2006). Striking a Balance Between Ethics and ICT Governance, Australasian Journal of Information Systems, Vol 13, No 2. http://dx.doi.org/10.3127/ajis.v13i2.53

Senarathna, I, Wilkin C, Warren, M, Yeoh, S \& Salzman S (2018). Factors that influence adoption of cloud computing: an empirical study of Australian SMEs, Australian Journal of Information Systems, Vol 22. http://dx.doi.org/10.3127/ajis.v22i0.1603

Senarathna, I, Warren, MJ, Yeoh, W \& Salzman, S (2016) Security and Privacy Concerns for Australian SMEs Cloud Adoption: Empirical Study of Metropolitan vs Regional SMEs, Australasian Journal of Information Systems, Vol 20. http://dx.doi.org/10.3127/ajis.v20i0.1193

Simpson, C., Nevile, L., \& Burmeister, O. K. (2003). Doing Ethics: A Universal Technique in an Accessibility Context. Australasian Journal of Information Systems, 10(2). doi:http://dx.doi.org/10.3127/ajis.v10i2.159

Teipel, S., Babiloni, C., Hoey, J., Kaye, J., Kirste, T., \& Burmeister, O. K. (2016). Information and communication technology solutions for outdoor navigation in dementia. Alzheimer's $\mathcal{E}$ Dementia: The Journal of the Alzheimer's Association, 12(6), 695-707. doi:10.1016/j.jalz.2015.11.003

Warren, M.J. and Hutchinson, W. (2003). Australian Hackers and Ethics, Australian Journal of Information Systems, Vol 10, No 2. http://dx.doi.org/10.3127/ajis.v10i2.163

Warren, M.J. and Hutchinson, W. (2001). Information Warfare and Ethics, Australian Journal of Information Systems, Vol 8, No 2. http://dx.doi.org/10.3127/ajis.v8i2.242

Copyright: () 2019 Burmeister \& Warren. This is an open-access article distributed under the terms of the Creative Commons Attribution-NonCommercial 3.0 Australia License, which permits non-commercial use, distribution, and reproduction in any medium, provided the original author and AJIS are credited. 


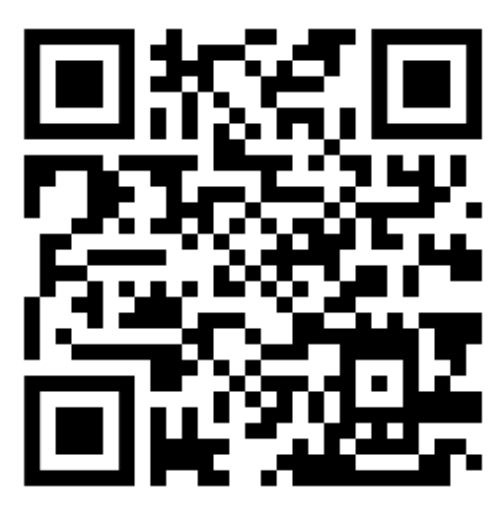

